\title{
On DiPSACUS AND DROSERA: Francis DARWIN'S FAVORITE CARNIVORES
}

John R. Schaefer - Harvard University - Department of the History of Science - Cambridge

- Massachusetts•USA・jschaefer@college.harvard.edu

Keywords: Dipsacus, Drosera, Francis Darwin, carnivory, insectivorous plants, common teasel.

Abstract: In autumn of 1875, Francis Darwin was busy researching aggregation in the tentacles of Drosera rotundifolia. This phenomenon occurs when colored particles within either "protoplasm" or the fluid in the cell vacuole (the cell sap) cluster together. Charles Darwin had theorized in the book Insectivorous Plants that these aggregated cellular masses consisted of living protoplasm. Inspired by his investigation of Drosera, Francis set out to examine the cup-like receptacles formed by the leaves of Dipsacus fullonum (synonym D. sylvestris), commonly known as fuller's teasel. Francis went on to suggest that the common teasel might be a carnivorous plant, acquiring nutrients from decaying insects drowned in its water-holding basins. Since then, other biologists have evaluated these claims with little experimental success. This paper provides a historical overview of Darwin's experiments with Dipsacus based on extant correspondence, discussing his results in the context of later studies that examine this unusual adaptation.

\section{Introduction}

Charles Darwin's enthusiasm for carnivorous plants is well documented. As early as 1860, soon after encountering the sundew Drosera rotundifolia on an English heath, the Origin of Species author wrote, "I care more about Drosera than the origin of all the species in the world" (Secord et al. 2020, Letter no. 2996). Darwin's rigorous experimentation with these enigmatic killer vegetables culminated in 1875 with the publication of Insectivorous Plants. This treatise laid the framework for the study of plant carnivory as it exists today and cemented the notion of carnivorous plants in the scientific and public imagination.

Darwin's son, Francis, carried on his father's legacy in a variety of ways, including through his own scientific ventures into plant carnivory. Francis' passion for carnivorous plants first stemmed from aiding in his father's work on Insectivorous Plants, in which he is credited with illustrating the tiny underwater traps of Aldrovanda and Utricularia. Drosera, however, was the resounding favorite of both father and son. Nearly two-thirds of Insectivorous Plants is dedicated to the sundew. Having firsthand experience with his father's experiments, Francis sought to elaborate on the book's findings shortly after the first edition was published.

In autumn of 1875, Francis Darwin was busy researching aggregation in the tentacles of Drosera rotundifolia (Darwin 1876). This phenomenon occurs when colored particles within either "protoplasm" or the fluid in the cell vacuole (the cell sap) cluster together. Darwin senior had theorized in Insectivorous Plants that these aggregated cellular masses consisted of living protoplasm (Secord et al. 2020, Letter no. 10134A). Inspired by his investigation of Drosera, Francis set out to examine the cup-like receptacles formed by the leaves of Dipsacus fullonum (synonym D. sylvestris), commonly known as fuller's teasel (Fig. 1). In The Loves of the Plants (1789) his great-grandfather, Erasmus Darwin, wrote that each dew-filled cup "serves both for the nutriment of the plant in dry seasons, and to prevent insects from creeping up to devour its seed." Francis, however, expected to find that the decaying insects known to accumulate in these cups were being absorbed by the plant. Unfortunately, the glandular hairs of his specimens were too withered for observation and he postponed 
work until the following summer. Using "some Teazle seeds" sent to his father from Kew Gardens by Joseph Dalton Hooker, Francis began growing his own specimens and continued collecting wild plants in the spring of 1876 (Secord et al. 2020, Letter no. 10282). The resulting observations would substantially further his foray into deciphering plant carnivory.

\section{"Hooray theory. Blow facts."}

On 28 May 1876, Francis wrote to his father that he had observed the protrusion of protoplasmic masses by the cells of Dipsacus glands, emphatically exclaiming "Hooray theory. Blow facts" (Secord et al. 2020, Letter no. 10515J). Francis drew comparisons to "the absorption of fat in the intestines" of animals by similar "protoplasmic feelers" and speculated that they may be the precursor to slimy secretions capable of catching live insects. Still finishing his article on aggregation in D. rotundifolia tentacles, Francis had to delay further examinations (Secord et al. 2020, Letter no. 10515I). His father encouraged pursuing this line of investigation and suggested further observations, imploring Francis "I would work at this subject if I were you, to the point of death" (Secord et al. 2020, Letter no. 10517).

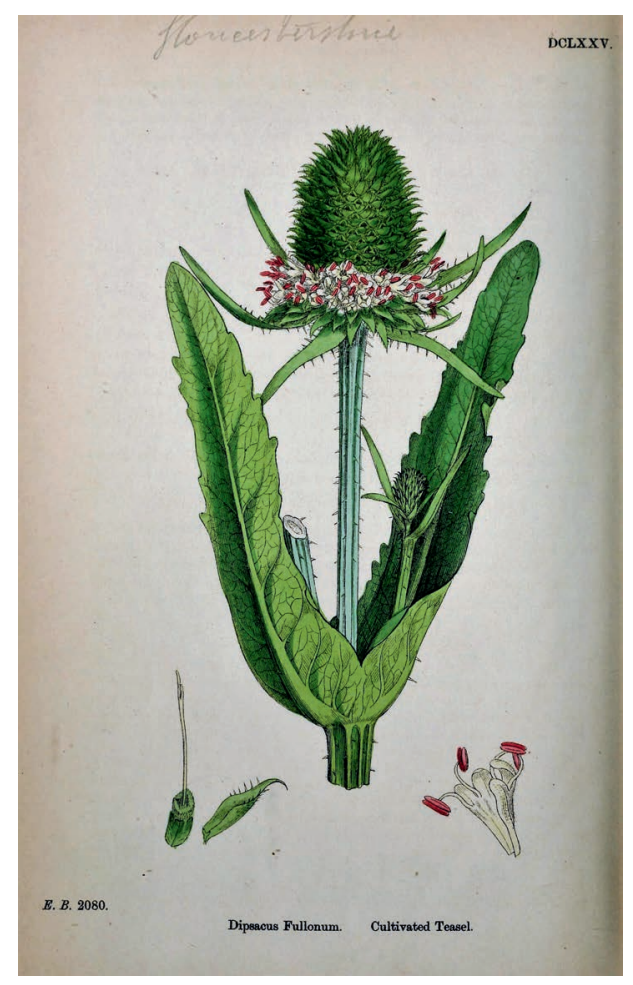

Figure 1: The connate leaves of Dipsacus fullonum form a water-holding basin. Sowerby (1865) plate 675.

At this time, Darwin senior was responding to critiques that Insectivorous Plants failed to conclusively prove these plants benefited from the absorption of insect matter. He was optimistic that by examining the effects of insect prey on growth and reproductive vigor (measured as biomass and quantity of seeds) such proof could be obtained and nudged his son towards attempting these "Seedbearing" experiments with Dipsacus (Secord et al. 2020, Letter no. 10517). While Darwin was "curious if the movements of the protoplasm depend on the excitement of ammonia or nitrogeneous matter", he also cautioned his son to "Take care and do not overwork and kill the goose that lays the golden eggs" (Secord et al. 2020, Letter no. 10525).

With his father's encouragement, Francis recorded "splendid protoplasmic movements" by exposing the glands to infusions of raw meat and carbonate of ammonia (Secord et al. 2020, Letter no. $10515 \mathrm{H})$. After witnessing this "grand discovery" himself, Darwin excitedly described the protoplasmic masses and movements to George John Romanes, FRS (Secord et al. 2020, Letter no. $10526,10520)$. In late June, Darwin confided to his friend J.D. Hooker, "I have hardly a doubt that here we have a plant catching \& feeding on solid particles of decaying insects" (Secord et al. 2020, Letter no. 10542).

Francis consulted with William Thiselton-Dyer of Kew Gardens by early July, and Darwin wrote to his second son, George Howard: "Frank is getting on very well with Dipsacus, \& has now made experiments which convince me that the matter which comes out of the glands is real live proto- 
plasm, about which I was beginning to feel horrid doubts." "Oh Lord what a set of sons I have, all doing wonders" (Secord et al. 2020, Letter no. 10556, 10561). Aside from a passing mention of Frank's endeavors to Asa Gray, there is no extant correspondence on the matter for the rest of the summer (Secord et al. 2020, Letter no. 10575). Although it can be surmised that Francis privately carried on with his observations.

On 7 September 1876, Francis welcomed his son Bernard into the world. He was the Darwin's first grandchild. However, tragedy soon struck the Darwin household. Francis' wife, Amy, died just four days after the birth of their son. Unable to live in their home in Down village, which reminded him so much of his life with Amy, a devastated Francis left for Wales with his in-laws, the Ruck's, a few days after her death. Bernard remained with his grandparents in Down. Worried that his son's despair would weaken his will to pursue scientific endeavors, Darwin gently yet consistently encouraged further work on a Dipsacus paper and frequently sent reading material to Wales (Secord et al. 2020, Letter no. 10611). Having suffered the deaths of two children, Darwin deeply believed in the value of finding solace through one's work. Francis entered a reclusive and hardworking state of mourning, continuing to work with Dipsacus as a distraction from his grief, and returned to Down House in mid-October (Secord et al. 2020, Letter no. 10635F, 10644). He spent the remainder of the year in his childhood home, authoring the Dipsacus paper and proofreading Darwin's second edition of Orchids (1877).

Initial publication and Royal Society reception

By January of the following year, the paper was nearly ready for publication, and Darwin senior submitted his son's discovery to the Royal Society of London. Only fellows of the Royal Society could submit research papers, and Francis was not yet a fellow. Personally, Darwin had high hopes that "its being printed...would stimulate his zeal \& make him think better of his work" (Secord et al. 2020, Letter no. 10814). Francis read his paper "On the protrusion of protoplasmic filaments from the glandular hairs of the common teasel (Dipsacus sylvestris)" at the Royal Society on 1 March 1877. His address was received with great "pride \& satisfaction" from longtime family friend J.D. Hooker, who worked extensively with the carnivorous tropical pitcher plant Nepenthes at Kew Gardens (Secord et al. 2020, Letter no. 10873). To this Darwin responded with equal enthusiasm, admitting that "Dipsacus will have to be examined by other good workers; but I do not think that anyone [could] see their spontaneous action \& doubt that they were formed of living matter" (Secord et al. 2020, Letter no. 10874).

An abstract of Francis' paper was published in the Royal Society's Proceedings, but to his father's malcontent the society neglected to print it in full: "The [Royal Society] Council have refused to print Frank's paper on the Teazle glands - on what grounds I know not. I have not been so much mortified for many a year; but he does not care much, all such things being mere trifles to him. My opinion about the value of his work remains quite unchanged \& I care not who the referees may have been" (Secord et al. 2020, Letter no. 10971). The full paper, complete with several of Francis' drawings and a plate of sixteen figures, was published July 1877 in the Quarterly Journal of Microscopical Science (Fig. 2).

Francis presented several key conclusions in his abstract: "the filaments contain true living protoplasm", "Dilute infusions of meat cause ... astonishing quantities of transparent matter [to be] produced", and "The protrusion of protoplasmic filaments from the glands of the teasel appears to bear an obscure relationship to the phenomena of 'aggregation' in Drosera and several other plants." He believed that the leaves were "adapted for the capture of insects whose decaying remains are 


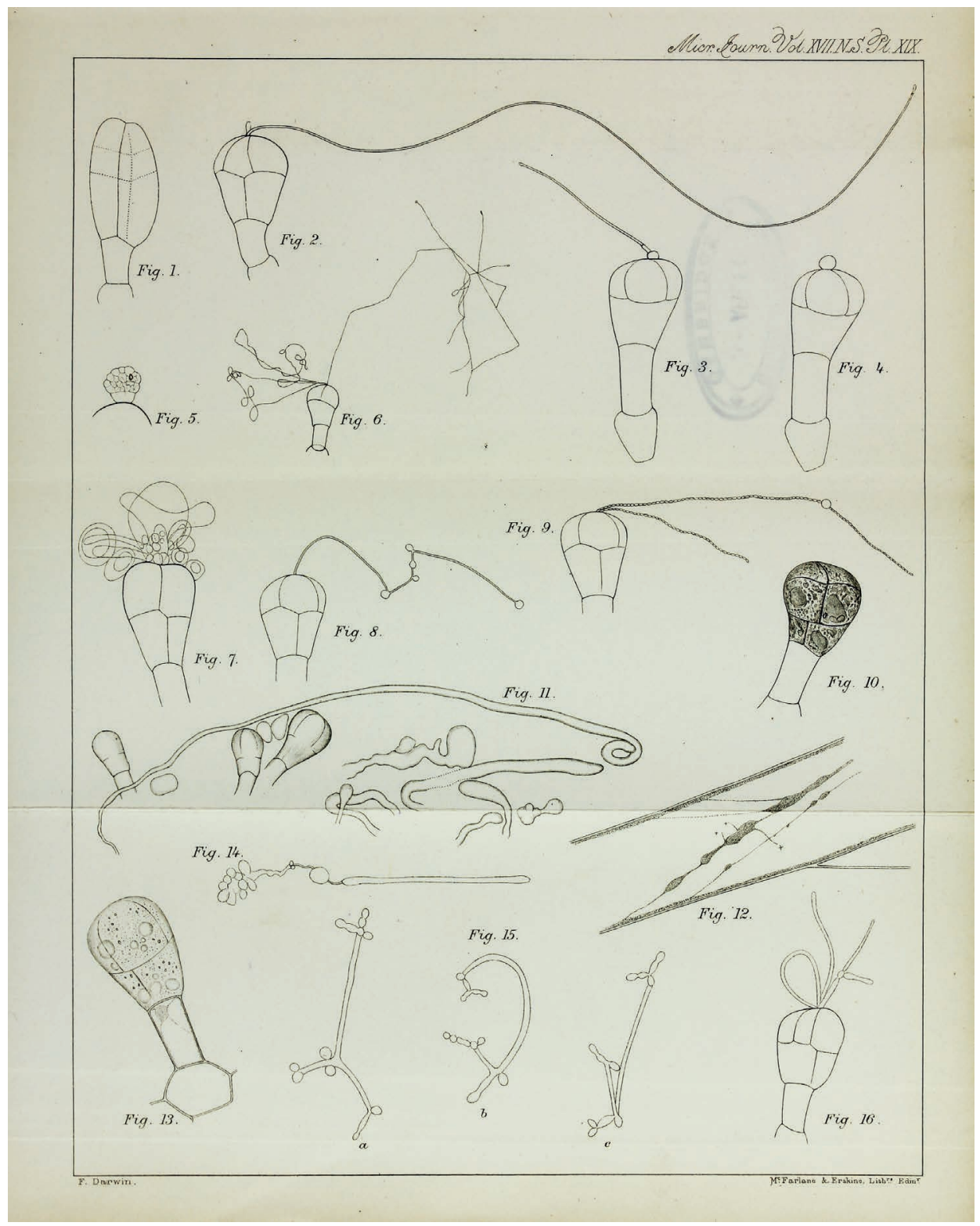

Figure 2: Plate from Francis Darwin's 1877 paper on the common teasel (Dipsacus sylvestris). Quarterly Journal of Microscopical Science s2-17(67): plate 19.

absorbed by the plant" and "form a pair of treacherous slides leading down to a pool of water." Francis stipulated that the protoplasmic filaments evolved first to absorb ammonia in accumulated rainwater, then adapted to consume drowned nitrogenous insect matter (Darwin 1877a). In his full paper, Francis proposed an experiment in which "teasel raised from seed under similar conditions will be divided into two lots, one half being starved and the other fed with insects or pieces of meat", 
not unlike his experiments on the growth and reproduction of Drosera (Darwin 1877b). There is no record of Francis following through with these plans.

An "extraordinary discovery"?

After its initial publication, Francis forwarded copies of the Dipsacus paper to several prominent scientists within his father's network of correspondence; most notably F.J. Cohn, Alphonse de Candolle, and Asa Gray. Cohn was particularly receptive to the "extraordinary discovery" and at Darwin's request successfully replicated Francis' observations by the beginning of August (Secord et al. 2020, Letter no. 11093). Still displeased by the Royal Society's decision not to publish the full paper, Darwin responded "I can declare that I have hardly ever received [a letter] in my life which has given me more pleasure. I have reason to know that some of our leading men of science disbelieve in my son's statements, \& this has mortified me not a little" (Secord et al. 2020, Letter no. 11095). At Darwin's request, Cohn agreed to allow an excerpt of his letter to be published in Nature, corroborating some of the "vital phenomena of protoplasmic pseudopodia" emerging from the teasel glands. Cohn's observations appeared in the journal by the end of the month (Darwin 1877). Although, as Darwin pointed out in a letter to G.J. Romanes, Cohn was hesitant to "pronounce whether the filaments are some colloid substance or living protoplasm" (Secord et al. 2020, Letter no. 11096).

On New Year's Eve Cohn revisited his initial reservations and wrote to Darwin that "after maturer reflection, I am convinced that there is no living phenomenon" taking place in the teasel filaments (Secord et al. 2020, Letter no. 11298). Cohn instead favored an entirely mechanical explanation, in which the exosmosis of water was responsible for the movement "of those curious filaments, protruding, undulating and retiring in the most extraordinary way" (Secord et al. 2020, Letter no. 11298). As early as August 1875, Cohn had argued that aggregation in Drosera resulted from the "partial precipitation of certain substances dissolved in the acid cell-fluid, in consequence of the exosmosis of the acid" (Secord et al. 2020, Letter no. 10137). While Cohn was mostly aligned with Darwin on the digestive properties of the protoplasmic Drosera exudate, he disagreed on the nature and function of aggregation. Francis' 1876 paper on aggregation sought explicitly to support his father's theory over Cohn's. That is, the aggregated masses consisted of protoplasm, rather than condensations of cell-sap (Darwin 1876). Cohn's comments on Dipsacus, however, went a step further. He became convinced that the exudate had no active (i.e., digestive) properties and was therefore not protoplasmic in nature.

Darwin was quick to defend his son, responding that Francis "has lately made some observations which incline me very strongly to believe that the filaments consist of living matter of the nature of protoplasm" (Secord et al. 2020, Letter no. 11310). He is referring to Francis' experiments on Amanita (Agaricus) muscaria (the fly agaric mushroom), from which Francis concluded that the filaments of both Agaricus and Dipsacus contracted as a result of living protoplasmic matter, rather than the endosmosis and exosmosis of water. When Francis witnessed the effect of salt and acid solutions on the filaments of both organisms, he conceded that "The two cases must sink or swim together" (Darwin 1878b). In this follow-up paper, he made it clear that his main research question was "Are the filaments protoplasmic or not?" This query took precedence over theories about the function of the filaments, and Francis distanced himself from his earlier speculation as to their carnivorous tendencies.

Indeed, after publishing his second Dipsacus paper, Francis appeared altogether done with the topic. Darwin attempted to nudge his son back towards "The Teazles" in the summer of 1879, exclaiming that they "look magnificent in the orchard, \& I hope next year you will grapple with the 
subject again, for I am sure that it is worth it" (Secord et al. 2020, Letter no. DAR 211:25). As late as 1881 , less than a year before his death, Darwin himself was experimenting with teasel leaves (Cambridge Digital Library). Yet it seems the coaxing of his father was not enough to rekindle Francis' scientific pursuit of the curious filaments. This is not to say his carnivorous curiosity was satiated completely. In 1888 he would publish a revised 2nd edition of Insectivorous Plants. Although there was no further mention of Dipsacus, Francis accepted that he and his father had erred on the nature of aggregation in Drosera: "there can be no doubt that the aggregated masses are ... precipitations of the cell-sap, and that their supposed amœboid movements are the result of the streaming protoplasm, which moulds the passive masses into a variety of forms" (Darwin 1888). Today, the "protrusions of protoplasm" beyond cell boundaries described by Darwin would typically be regarded as cytoplasmic exudates.

\section{Dipsacus beyond Darwin}

Extant correspondence tells us that Francis Darwin's observations of Dipsacus were the natural continuation of a scientific legacy firmly grounded in his father's work. Although many of Darwin's experiments remain the foundation of modern carnivorous theory, he avoided any extensive discussion of their evolutionary development. Francis' examination of D. fullonum provided a "missing link" of sorts, in that he believed this plant had evolved protoplasmic features for other purposes, but that they had begun to benefit the plant in carnivorous ways. This discovery opened the door to the scientific evaluation of sub-carnivorous plants, further blurring the increasingly complex boundaries of the plant kingdom.

Detractors of Charles Darwin's carnivorous theory frequently pointed out that so-called carnivorous plants flourished in European hothouses year-round without any insect prey to feed on. Experiments executed during the writing of Insectivorous Plants attempted to address this quandary but failed as all the plants, fed or not, had died. Francis returned to his father's beloved Drosera rotundifolia in June 1877, finding sundews that had been "fed" doubled in seed production and size (Darwin 1878a). Since these early experiments, many carnivorous genera have been proven to demonstrate increased size and biomass when the plants are supplemented with insect prey.

By the early 20th century, biologists inspired by Francis Darwin sought to determine the common teasel's status as a carnivorous plant. In 1904, Rostock published a wide-ranging study on the glands, their curious "filaments" and the absorptive properties of $D$. fullonum, finding no detectable absorption of various nitrogen compounds by the cups. His study involved several feeding experiments in which the test group was supplied insect prey, while the cups of one control group were slit open so that they could not hold water, and water in the cups of another control group was replaced daily so that nutrients/prey could not accumulate (Rostock 1904). At the conclusion of the experiment all observed parameters (size, robustness, fertility) were essentially comparable regardless of treatment. Only the control with perforated cups was less strongly branched (possibly because buds were injured by the cuts) and consequently these plants produced fewer fruits (Rostock 1904). Thus, Rostock determined that the cups did not provide any meaningful nutritional benefit to the plants.

Nearly two decades later, Miller Christy (1923) offered abundant circumstantial observations and speculations but very little experimental evidence for his bold assertion of "The common teasel as a carnivorous plant." Admitting that he had "no conclusive proof", Christy's claims have remained largely anecdotal. Later authors such as Juniper, Robins and Joel (1989) did not consider Dipsacus to be carnivorous. Additionally, while Cohn (1878) assumed osmotic expansion of an exudate, Senft (1907) provided a more plausible explanation by attributing the filaments to "myelin 
figures." Long, thin, cylindrical structures that form spontaneously at the interface between certain lipids/surfactants with water, their movement is driven by abiotic forces and often creates dense tangled masses like those observed by Darwin. Senft's interpretation appears to have held up over time, although the work of both Senft and Rostock has been mostly ignored in recent literature - with the notable exception of Vogel (1974), who discussed these so-called myelin figures in some detail.

Despite - or perhaps simply unaware of - Rostock's discouraging findings, contemporary attempts to replicate these experiments on the common teasel continue to fuel debate over whether or not Dipsacus truly boasts a carnivorous appetite. A 2011 study (Shaw \& Shackleton 2011) revealed significant differences in seed production dependent on both amount and nature of introduced animal supplementation, while 2019 experiments suggested that increased seed production was a response to poor soil conditions rather than proof of carnivory (Krupa \& Thomas 2019). Krupa and Thomas (2019) further posited that examining the cups as mechanisms of predatory deterrence against insects remains the most plausible untested hypothesis; first proposed by Erasmus Darwin in The Loves of the Plants (1789). Experimental evaluation of this theory is a sound next step in solving the mystery of Dipsacus' unusual adaptation. Although Francis Darwin's initial hypothesis seems to have been promptly proven false by Rostock, his original conviction (shared by his father) appears to be seeing a minor resurgence some century and a half later, and these results are almost certainly not the final words on the matter.

Acknowledgements: This paper was originally written as commentary for the Darwin Correspondence Project. It is based on research conducted through a Harvard Museum of Comparative Zoology Grant during summer 2020 under the invaluable supervision of Dr. Janet Browne and was made possible by the generous feedback and support of Dr. Alison Pearn, Ms. Shelley Innes, and Dr. Francis Neary of the Darwin Correspondence Project at the University of Cambridge. Thank you to Dr. Jan Schlauer for helpful editorial comments and additional source material.

\section{References}

Cambridge Digital Library. Darwin Manuscripts: Notes, 1868-1882. Botanical Topics, Variation, Pangenesis. Accessed 8 September 2020. https://cudl.lib.cam.ac.uk/view/MS-DAR-00052/209. Christy, M. 1923. The common teasel as a carnivorous plant. J. Bot. 61: 33-45.

Cohn, F.J. 1878. Über vibrirende Fäden in den Drüsenhaaren von Dipsacus. Botanische Zeitung 36: 122-124.

Darwin, C. 1877. The contractile filaments of the teasel. Nature 16: 339.

Darwin, C. 1888. Insectivorous Plants. 2d ed. Revised by Francis Darwin. London: John Murray.

Darwin, E. 1789. The Botanic Garden, Part II: Containing The Loves of the Plants, a Poem: With Philosophical Notes. Lichfield.

Darwin, F. 1876. The process of aggregation in the tentacles of Drosera rotundifolia. Journal of Cell Science s2-16(63): 309-319.

Darwin, F. 1877a. On the protrusion of protoplasmic filaments from the glandular hairs of the common teasel (Dipsacus sylvestris). (Abstract.) [Read 1 March 1877.] Proceedings of the Royal Society of London 26: 4-8.

Darwin, F. 1877b. On the protrusion of protoplasmic filaments from the glandular hairs on the leaves of the common teasel (Dipsacus sylvestris). Quarterly Journal of Microscopical Science s2-17(67): 245-272.

Darwin, F. 1878a. Experiments on the nutrition of Drosera rotundifolia. Botanical Journal of the Linnean Society, 17(98): 17-31. 
Darwin, F. 1878b. The contractile filaments of Amanita (Agaricus) Muscaria and Dipsacus Sylvestris. Journal of Cell Science s2-18(69): 74-82.

Juniper, B.E., Robins, R.J., and Joel, D.M. 1989. The Carnivorous Plants. London; San Diego: Academic Press.

Krupa, J.J., and Thomas, J.M. 2019. Is the common teasel (Dipsacus fullonum) carnivorous or was Francis Darwin wrong? Botany 97(6): 321-328.

Rostock, R. 1904. Ueber die biologische Bedeutung der Drüsenhaare von Dipsacus sylvestris. Botanische Zeitung 62: 11-20.

Secord, J.A. et al. (12 co-editors and more than 79 contributors) 2020. Darwin Correspondence Project. Accessed 15 December 2020. https://www.darwinproject.ac.uk/.

Senft, E. 1907. Über die Myelinformen bildende Substanz in Ginkgo-Samen. Pharm. Post 40: 265271, 287-289, 304-307, 319-321: 288.

Shaw, P.J.A., and Shackleton, K. 2011. Carnivory in the teasel Dipsacus fullonum - The effect of experimental feeding on growth and seed set. PLOS ONE 6(3), e17935.

Sowerby, J. 1865. English botany, or, Coloured figures of British plants, ed. 3, vol. 4: plate 675. London: R. Hardwicke.

Vogel, S. 1974. Ölblumen und ölsammelnde Bienen, vol. 1: 118-120.
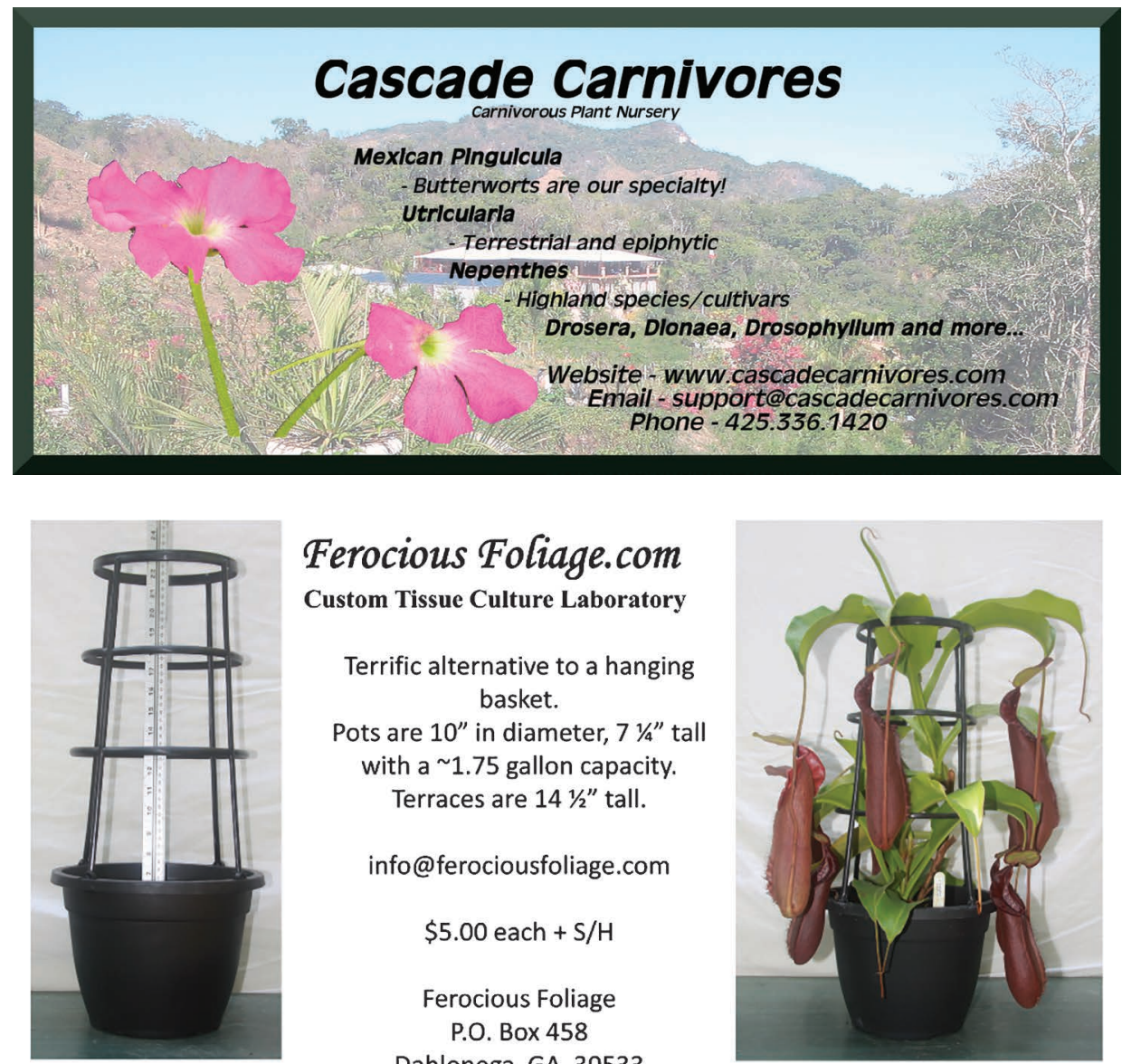

\section{Ferocious Foliage.com}

Custom Tissue Culture Laboratory

Terrific alternative to a hanging basket.

Pots are $10^{\prime \prime}$ in diameter, $71 / 4^{\prime \prime}$ tall with a 1.75 gallon capacity.

Terraces are $14 \frac{1 / 2}{\prime \prime}$ tall.

info@ferociousfoliage.com

$$
\$ 5.00 \text { each }+\mathrm{S} / \mathrm{H}
$$

Ferocious Foliage

P.O. Box 458

Dahlonega, GA 30533

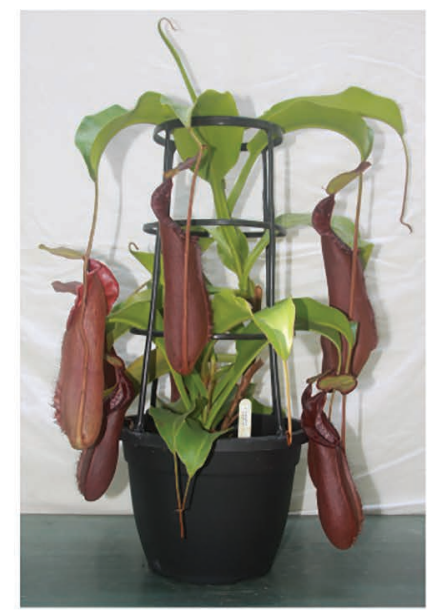

Plant not included 